\title{
Laboratory note
}

\section{Detection of lard in a complex dehydrated stock}

\author{
By M. Balsells, E. Bota *, R. Clotet and M. Suque \\ Escola Superior D'Agricultura de Barcelona. Dpt. d'Industries Agro-Alimentaries. c/ C. D'Urgell, 187. 08036 Barcelona. \\ * To whom inquiries should be addressed
}

\section{RESUMEN}

Detección de grasa de cerdo en caldo deshidratado.

La detección de grasa de cerdo en un producto alimentario presenta un gran interés por motivos de calidad, dietéticos o de creencias religiosas.

Los trabajos realizados hasta el presente han incidido fundamentalmente en mezclas de grasas.

En el presente trabajo se estudia un alimento complejo (modelo de caldo deshidratado) que contiene grasa de palma hidrogenada y grasa de buey. Se valora la sensibilidad de detección frente a la adición de un $0,2 \%$ de grasa de cerdo utilizando datos de esteroles y de los ácidos grasos en posición $\beta$. Sólo este último método aparece fiable para el objetivo propuesto.

PALABRAS-CLAVE: Análisis - Caldo deshidratado - Grasa de cerdo.

SUMMARY

Detection of lard in a complex dehydrated stock.

The detection of lard in food products is of special interest for reasons of quality, dietetics or religious belief.

Works carried out to date have mainly concerned fatty mixtures with others food components.

This work studies a complex food products (dehydrated stock model) containing hydrogenated palm and beef fat. An appraisal is carried out regarding the detection sensitivity to the addition of $0.2 \%$ lard, using data on sterols and fatty acids in the $\beta$ position. This last model only appears reliable for the goal proposed.

KEY-WORDS: Analysis - Dehydrated stock - Lard.

\section{INTRODUCTION}

The availability of a reliable system to detect lard in food products is important, be it for control purposes of a formerly established standard or for reasons of religious belief.

The detection of lard in simple fatty mixtures is a problem that has been treated by several researchers. Wolff, J. P. and Audiau, F. (1964) already explored the possibility of detecting the presence of lard in binary mixtures with other animal fats, by means of the global profile of the composition of fatty acids. The sterol ratio also started to be used (Wolff, J. P. (1968)) as an indicator of this contamination. More recently, Rugraff, L. and Karleskind, A. (1983); El-Sayed, L. et al. (1985); Youssef, M.K.E. et al. (1986a) (1986b); El-Khalafy, H. M. et al. (1987a) (1987b); Youssef, M.K.E. and Rashwan, M.R.A. (1987); Fahmy, L. et al. (1988); Youssef, M.K.E. et al. (1988); and Saeed, T. et al. (1989), introduced the control, already using in some cases, triglyceride separation and the study of its structure or the presence of a specific indicator (acid 11.14 -eicosadienoic- $\mathrm{C}_{20.2}$ ) (Saeed, T. et al. (1986)) or the control of alcoholic, aldehydic and heterocyclic compounds using mass spectrometry after a separation by gas chromatography (Fadel, H. M. and Soliman, M. H. A., 1989).

In every case, the goal is to detect the presence of lard in simple fatty mixtures.

The lard detection problem in complex foods, in which there can often be a mixture of hydrogenated -or notvegetable and animal fats, together with the fatty fraction from other components not considered conventionally as fats, has not yet been treated systematically. Only Saeed, T. et al. (1989) 's work refers to processed meats and mentions the possibility of its application in biscuits, without any experimental control being carried out.

In this work, the possibility of detecting the presence of lard in complex food compositions, such as stock or dehydrated soup that can contain fatty mixtures (hydrogenated or not) and complex products such as hydrolysed protein, beef meat and yeast extracts, salt, spices, dehydrated meat and ingredients with a considerable fatty fraction such as, powdered milk, dehydrated egg, etc.

A dehydrated stock mixture of complex composition, that also contains hydrogenated palm and beef fats has been used. Several samples of this mixture have been contaminated with lard $(0,2 \%)$. The addition of an $0.2 \%$ was chosen, having found in previous works that for lower levels of contamination, the reliability of a control was less than $95 \%$ with regard to the variabiliy of the raw materials.

To detect the contamination two analytical ways are applied to all the samples, based on the determination of the sterol composition and that of the fatty acids in the $\beta$ position, and the results compared. 


\section{MATERIAL AND METHODS}

\subsection{Dehydrated stock mixture}

Product obtained by adequately mixing the following ingredients:

Hydrolysed vegetable protein .......................... $\quad 6.5$

Monosodium glutamate ................................. 12.0

Starch ............................................................. 13.0

Dry vegetables ............................................... $\quad 2.0$

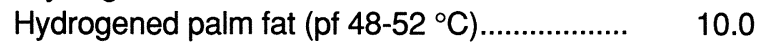

Beef fat ...................................................... 0.5

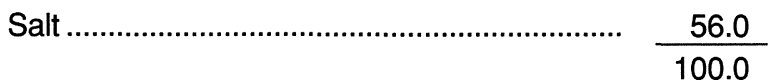

With the same quantitative formulation, ten different mixtures were prepared, changing the fats which in each case, maintained their identities, but came from different industrial lots.

Six groups of this products were also contaminated with $0.2 \%$ lard.

The identity of the palm fat was checked irrefutably by analytical way and the animal fats were obtained directly from the slaughterhouse (see Table la - lb - Ic).

\subsection{Free fat content}

Soxhlet extraction with petroleum ether (boiling p. 40$60^{\circ} \mathrm{C}$ ) as described in the official A.I.I.B.P. methods (1990).

\subsection{Sterols}

As per UNE 55-019-73 Standard: «Fatty matter: Analysis of the sterol fraction by gas chromatography».
Table lb

Contents of sterols, fatty acids and fatty acids in the $\beta$ position in beef fats

\begin{tabular}{|c|c|c|c|c|}
\hline \multicolumn{2}{|c|}{ Parameters Ref. } & 1 & 2 & 3 \\
\hline 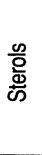 & $\begin{array}{l}\text { Cholesterol } \\
\text { Campesterol } \\
\text { Stigmasterol } \\
\beta \text {-sitosterol }\end{array}$ & $\begin{array}{r}100 \\
- \\
- \\
-\end{array}$ & $\begin{array}{r}100 \\
- \\
- \\
-\end{array}$ & $\begin{array}{r}100 \\
- \\
- \\
-\end{array}$ \\
\hline 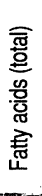 & $\begin{array}{l}\text { Palmitic } \\
\text { Palmitoleic } \\
\text { Stearic } \\
\text { Oleic } \\
\text { Linoleic }\end{array}$ & $\begin{array}{r}26.29 \\
3.41 \\
23.68 \\
42.40 \\
4.22 \\
\end{array}$ & $\begin{array}{r}22.20 \\
3.43 \\
24.96 \\
44.75 \\
4.66 \\
\end{array}$ & $\begin{array}{r}30.86 \\
4.26 \\
19.73 \\
41.76 \\
3.39 \\
\end{array}$ \\
\hline 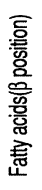 & $\begin{array}{l}\text { Palmitic } \\
\text { Palmitoleic } \\
\text { Stearic } \\
\text { Oleic } \\
\text { Linoleic }\end{array}$ & $\begin{array}{r}21.44 \\
6.37 \\
5.93 \\
56.58 \\
9.68\end{array}$ & $\begin{array}{r}20.47 \\
4.42 \\
10.95 \\
56.03 \\
8.13\end{array}$ & $\begin{array}{r}25.57 \\
6.34 \\
8.57 \\
53.28 \\
6.24\end{array}$ \\
\hline
\end{tabular}

\subsection{Fatty acids in the $\beta$ position}

As per ISO 6800-1985 Standard: «Animal and vegetable fats and oils. Determination of the composition of fatty acids in the 2 position".

The methodology is described for fats with a melting point lower than $45^{\circ} \mathrm{C}$. In the type of product under study -as has been prepared in the product model used-hydrogenated fats are such up to a melting point ranging from 48 to $52^{\circ} \mathrm{C}$. Reproducible results are obtained if a double hydrolysis of triglycerides with lipase (8.5. of the above mentioned Standard) is made. The effectiveness of this modification can also be seen in the perfect separation of

Table la

Contents of sterols, fatty acids, fatty acids in the $\beta$ position in hydrogenated palm fats

\begin{tabular}{|c|c|c|c|c|c|c|c|c|c|c|c|}
\hline \multicolumn{2}{|c|}{ Parameters } & 1 & 2 & 3 & 4 & 5 & 6 & 7 & 8 & 9 & 10 \\
\hline \multirow{4}{*}{$\begin{array}{l}\frac{0}{0} \\
\frac{0}{\Phi} \\
\dot{\omega}\end{array}$} & Cholesterol & 3.29 & 2.30 & 3.55 & 2.79 & 4.46 & 5.71 & 3.95 & 2.10 & 2.70 & 2.04 \\
\hline & Campesterol & 21.57 & 21.74 & 21.15 & 20.46 & 20.59 & 21.86 & 21.58 & 21.75 & 21.78 & 20.59 \\
\hline & Stigmasterol & 13.00 & 12.78 & 13.04 & 13.59 & 12.63 & 13.74 & 11.73 & 14.36 & 12.94 & 13.88 \\
\hline & $\beta$-sitosterol & 62.14 & 63.18 & 62.26 & 63.16 & 62.32 & 58.69 & 62.74 & 61.79 & 62.58 & 63.49 \\
\hline \multirow{6}{*}{ 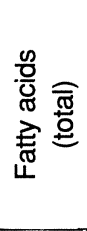 } & Miristic & 1.06 & 1.22 & 1.10 & 1.10 & 1.19 & 1.05 & 1.07 & 1.17 & 1.04 & 1.12 \\
\hline & Palmitic & 45.67 & 49.12 & 48.47 & 44.95 & 46.96 & 45.26 & 44.47 & 47.24 & 44.75 & 47.55 \\
\hline & Palmitoleic & - & - & - & - & - & - & - & - & - & - \\
\hline & Stearic & 14.90 & 10.52 & 8.03 & 12.46 & 11.89 & 13.14 & 14.89 & 8.89 & 14.55 & 9.74 \\
\hline & Oleic & 38.37 & 38.83 & 42.24 & 41.25 & 39.65 & 40.55 & 39.50 & 42.38 & 39.52 & 41.59 \\
\hline & Linoleic & - & 0.31 & 0.16 & 0.24 & 0.31 & - & 0.07 & 0.32 & 0.14 & - \\
\hline \multirow{6}{*}{ 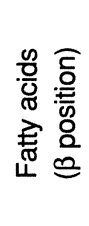 } & Miristic & 0.83 & 0.72 & 0.89 & 1.16 & 0.95 & 1.33 & 0.63 & 0.89 & 0.69 & 0.87 \\
\hline & Palmitic & 19.06 & 20.89 & 20.51 & 18.41 & 22.39 & 19.81 & 17.07 & 22.22 & 19.43 & 19.02 \\
\hline & Palmitoleic & 1.11 & 1.10 & 0.80 & 1.06 & 0.58 & 1.40 & 0.80 & 0.44 & 0.48 & 0.30 \\
\hline & Stearic & 17.47 & 9.26 & 5.72 & 12.16 & 11.82 & 14.09 & 15.57 & 7.04 & 15.10 & 8.04 \\
\hline & Oleic & 60.15 & 66.15 & 71.07 & 65.23 & 63.72 & 61.93 & 63.80 & 68.25 & 63.48 & 71.27 \\
\hline & Linoleic & 1.38 & 1.88 & 1.01 & 1.98 & 0.54 & 1.44 & 2.13 & 1.16 & 0.82 & 0.50 \\
\hline
\end{tabular}


the two monoglycerides (8.6.2), which does not occur when a single treatment is carried out. In our case, control of the lipasic activity is carried out at $40^{\circ} \mathrm{C}$ (A.2.).

Tablè ic

Contents of sterols, fatty acids and fatty acids in the $\beta$ position in lards

\begin{tabular}{|c|c|c|c|c|}
\hline \multicolumn{2}{|c|}{ Parameters Ref. } & 1 & 2 & 3 \\
\hline$\frac{\mathscr{\infty}}{\stackrel{0}{\circ}}$ & $\begin{array}{l}\text { Cholesterol } \\
\text { Campesterol } \\
\text { Stigmasterol } \\
\beta \text {-sitosterol }\end{array}$ & $\begin{array}{r}100 \\
- \\
-\end{array}$ & $\begin{array}{r}100 \\
- \\
-\end{array}$ & $\begin{array}{r}100 \\
- \\
- \\
-\end{array}$ \\
\hline 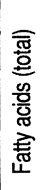 & $\begin{array}{l}\text { Palmitic } \\
\text { Palmitoleic } \\
\text { Stearic } \\
\text { Oleic } \\
\text { Linoleic }\end{array}$ & $\begin{array}{r}29.33 \\
2.15 \\
20.62 \\
38.24 \\
9.66\end{array}$ & $\begin{array}{r}28.52 \\
2.18 \\
18.90 \\
41.28 \\
9.12\end{array}$ & $\begin{array}{r}27.90 \\
3.07 \\
15.34 \\
40.27 \\
13.42\end{array}$ \\
\hline 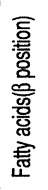 & $\begin{array}{l}\text { Palmitic } \\
\text { Palmitoleic } \\
\text { Stearic } \\
\text { Oleic } \\
\text { Linoleic }\end{array}$ & $\begin{array}{r}70.88 \\
5.61 \\
4.00 \\
16.51 \\
3.00\end{array}$ & $\begin{array}{r}73.39 \\
5.71 \\
3.12 \\
13.22 \\
4.56\end{array}$ & $\begin{array}{r}70.00 \\
4.93 \\
4.65 \\
15.40 \\
5.02\end{array}$ \\
\hline
\end{tabular}

\subsection{Total fatty acids}

As per UNE 55-037-73 Standard: «Fatty matter: Determination of fatty acids by gas chromatography».

\section{RESULTS}

The application of the above mentioned analysis methods to the 10 replicates, gave the values in Table II for sterol, fatty acid and fatty acid in the $\beta$ position contents. In each case, only the main components that are fundamental for the focus of this work, are indicated.

Table III shows the results of the data found from adding $0.2 \%$ lard to the aforementioned dehydrated products $3,4,5,8,9$ and 10 .

\section{DISCUSSION AND CONCLUSIONS}

The analytic data in Table II (products without added lard) allowed to determine the indexes used as a lard-indicating parameter, having first used the sterol content as an indicating parameter. Table IV shows the $\beta$ sitosterol/cholesterol ratio for each sample, having determined the lard contamination based on the sterol quotient values (Wolff, J. P. (1968), according to the formula:

$$
\% \text { Lard }=\frac{1,9-0,10 S}{5,9 S+1,9} \times 100
$$

with $S$ as the $\beta$-sitosterol/cholesterol ratio, the theoretical contaminations shown in the same Table are obtained.

Likewise, the same Table IV includes the parameter developed by us from the composition of fatty acids:

$$
R=\frac{C_{16}}{C_{18: 0}+C_{18: 1}+C_{18: 2}} \times 100 \text { (all in } \beta \text { position) }
$$

and the enrichment factor:

Table II

Contents of sterols, fatty acids and fatty acids in the $\beta$ position in replicates of a dehydrated stock

\begin{tabular}{|c|c|c|c|c|c|c|c|c|c|c|c|}
\hline \multicolumn{2}{|c|}{ Parameters Ref. } & 1 & 2 & 3 & 4 & 5 & 6 & 7 & 8 & 9 & 10 \\
\hline \multirow{4}{*}{$\frac{\frac{N}{O}}{\Phi}$} & Cholesterol & 13.36 & 13.38 & 15.08 & 16.02 & 15.86 & 16.64 & 11.64 & 11.52 & 12.85 & 9.10 \\
\hline & Campesterol & 15.19 & 11.99 & 16.71 & 13.52 & 14.31 & 14.97 & 14.30 & 13.82 & 16.63 & 14.89 \\
\hline & Stigmasterol & 18.05 & 23.80 & 17.92 & 25.82 & 14.93 & 18.37 & 23.57 & 17.64 & 16.94 & 17.45 \\
\hline & $\beta$-sitosterol & 53.40 & 50.83 & 50.29 & 44.64 & 54.90 & 50.02 & 50.49 & 57.02 & 53.58 & 58.56 \\
\hline \multirow{6}{*}{ 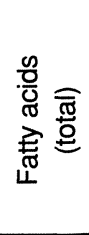 } & Miristic & 1.23 & 1.40 & 1.20 & 1.66 & 1.72 & 1.20 & 1.37 & 1.89 & 1.80 & 2.19 \\
\hline & Palmitic & 48.91 & 48.86 & 56.20 & 57.64 & 50.28 & 45.24 & 45.12 & 52.39 & 50.16 & 56.02 \\
\hline & Palmitoleic & 0.48 & 0.55 & 0.12 & 0.49 & 0.55 & 0.44 & 0.47 & 0.51 & 0.46 & 0.10 \\
\hline & Stearic & 15.41 & 10.68 & 8.10 & 10.91 & 12.57 & 16.84 & 11.76 & 13.15 & 14.31 & 10.79 \\
\hline & Oleic & 33.61 & 37.17 & 33.47 & 28.96 & 33.97 & 35.47 & 40.21 & 31.22 & 32.54 & 29.90 \\
\hline & Linoleic & 0.36 & 1.34 & 0.91 & 0.34 & 0.91 & 0.81 & 1.07 & 0.84 & 0.73 & 1.00 \\
\hline \multirow{6}{*}{ 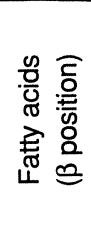 } & Miristic & 0.76 & 0.98 & 1.09 & 1.00 & 1.44 & 1.00 & 0.96 & 1.35 & 0.94 & 1.14 \\
\hline & Palmitic & 18.12 & 21.65 & 20.77 & 19.26 & 20.95 & 18.56 & 18.66 & 22.52 & 19.83 & 22.32 \\
\hline & Palmitoleic & 0.58 & 1.34 & 8.40 & 0.80 & 0.98 & 1.12 & 0.65 & 0.62 & 0.59 & 0.46 \\
\hline & Stearic & 17.63 & 7.04 & 12.29 & 8.13 & 13.30 & 15.87 & 12.57 & 12.71 & 14.80 & 13.33 \\
\hline & Oleic & 62.34 & 66.89 & 55.28 & 67.66 & 61.98 & 61.76 & 65.31 & 61.09 & 62.96 & 61.34 \\
\hline & Linoleic & 0.57 & 2.10 & 2.17 & 3.15 & 1.35 & 1.69 & 1.85 & 1.71 & 0.88 & 1.41 \\
\hline
\end{tabular}
which composition is indicated in the text 
Table III

Replicates of the fatty acid and fatty acid in the $\beta$ position contents in dehydrated stock, with added lard

\begin{tabular}{|c|c|c|c|c|c|c|c|}
\hline \multicolumn{2}{|c|}{ Parameters } & $\begin{array}{l}\text { Rf. } 3+0,2 \% \\
\text { Lard }\end{array}$ & $\begin{array}{c}\text { Rf. } 4+0,2 \% \\
\text { Lard }\end{array}$ & $\begin{array}{l}\text { Rf. } 5+0,2 \% \\
\quad \text { Lard }\end{array}$ & $\begin{array}{c}\text { Rf. } 8+0,2 \% \\
\text { Lard }\end{array}$ & $\begin{array}{c}\text { Rf. } 9+0,2 \% \\
\text { Lard }\end{array}$ & $\begin{array}{c}\text { Rf. } 10+0,2 \% \\
\text { Lard }\end{array}$ \\
\hline \multirow{6}{*}{ 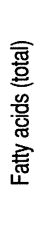 } & Miristic & 1.37 & 2.20 & 1.42 & 1.83 & 1.65 & 1.77 \\
\hline & Palmitic & 47.79 & 53.00 & 45.02 & 51.22 & 48.49 & 52.53 \\
\hline & Palmitoleic & 0.68 & 0.64 & 0.56 & 0.22 & 0.55 & 0.56 \\
\hline & Stearic & 9.20 & 10.98 & 13.10 & 13.83 & 15.15 & 11.65 \\
\hline & Oleic & 39.79 & 32.44 & 38.60 & 32.05 & 33.45 & 31.87 \\
\hline & Linoleic & 1.17 & 0.74 & 1.30 & 0.85 & 0.71 & 1.62 \\
\hline \multirow{6}{*}{ 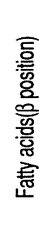 } & Miristic & 1.70 & 1.80 & 1.60 & 1.31 & 1.48 & 1.00 \\
\hline & Palmitic & 24.79 & 26.99 & 22.51 & 29.53 & 24.47 & 29.09 \\
\hline & Palmitoleic & 5.28 & 2.26 & 1.19 & 0.46 & 0.71 & 0.54 \\
\hline & Stearic & 15.26 & 11.39 & 8.28 & 14.88 & 15.11 & 12.70 \\
\hline & Oleic & 49.25 & 55.66 & 64.11 & 53.41 & 56.90 & 55.16 \\
\hline & Linoleic & 3.72 & 1.90 & 2.31 & 0.41 & 1.33 & 1.51 \\
\hline
\end{tabular}

Table IV

$\beta$-sitosterol/cholesterol ratios and $\mathbf{R}$ and $\mathrm{EF}_{\text {palm }}$ values for the replicates studied

\begin{tabular}{|c|c|c|c|c|c|c|c|c|c|c|c|}
\hline \multirow[b]{2}{*}{ Parameter } & \multicolumn{10}{|c|}{ REPLICATE } & \\
\hline & 1 & 2 & 3 & 4 & 5 & 6 & 7 & 8 & 9 & 10 & \\
\hline $\begin{array}{l}\beta \text {-sitosterol } \\
\text { /cholest. (S) }\end{array}$ & 4.0 & 3.8 & 3.3 & 2.8 & 3.5 & 3.0 & 4.3 & 4.9 & 4.2 & 6.4 & \\
\hline $\begin{array}{l}\% \text { Lard obtained } \\
\text { by calculation }\end{array}$ & 5.9 & 6.2 & 7.3 & 8.8 & 6.9 & 8.2 & 5.4 & 4.6 & 5.5 & 3.2 & $\bar{x} \pm 3 \sigma$ \\
\hline $\mathrm{R}$ & 22.50 & 28.48 & 29.78 & 24.39 & 27.34 & 23.40 & 23.40 & 29.83 & 25.22 & 29.34 & $26.37 \pm 8.25$ \\
\hline $\mathrm{EF}_{\mathrm{palm}}$ & 0.37 & 0.44 & 0.37 & 0.33 & 0.42 & 0.41 & 0.41 & 0.43 & 0.40 & 0.40 & $0.40 \pm 0.09$ \\
\hline
\end{tabular}

$$
E F_{\text {palm }}=\frac{\% \text { palmitic en } \beta \text { pos. }}{\% \text { total palmitic }} \text { (fat basis) }
$$

Results in Table IV indicated mistaken positive results when sterols indexes are used. On the other hand the values $E F$ palm are not representative of the contamination, according to the criterion of El-Sayed et al. (1985) $(<1$ and $\geq 3$ ) for simple fat mixtures.

The values obtained from the application of the $R$ and EF palm parameters to the contaminated samples are shown in Table $\mathrm{V}$.

The results show, for all the cases reviewed, a significant increase $(p>0,997)$ in EF palm as regards the values of the ten non contaminated replicates. From the results available, the proposed value for $\mathrm{R}$ is nor as reliable.
From the results described, it follows that for fatty mixtures in food products such as those described and which contain other animal fats and palm vegetable fat (one of the vegetable fats with the highest cholesterol content), to use the sterol ratio always gives falsely positive results with a mistaken high lard contamination percentage. On the other hand, to use the ratios based on the $\beta$ position of triglycerides give a correct result as no false positives are obtained and as minimum $0.2 \%$ lard contamination in the product ( $2 \%$ fat basis) is already detectable.

It therefore follows that for complex products, such as those described containing animal and hydrogenated palm vegetable fats and small amount of fat coming from other ingredients (as vegetables, hydrolysed vegetable protein), the application of the sterol quotient may lead to error, and that it is possible to use, with the changes mentioned, the

Table V

$R$ and $E F$ palm values for the lard-contaminated samples

\begin{tabular}{|l|ccccccc|}
\hline Ref. & $\begin{array}{c}\text { Rf.3+0.2\% } \\
\text { Lard }\end{array}$ & $\begin{array}{c}\text { Rf. } 4+0.2 \% \\
\text { Lard }\end{array}$ & $\begin{array}{c}\text { Rf.5+0.2\% } \\
\text { Lard }\end{array}$ & $\begin{array}{c}\text { Rf.8+0.2\% } \\
\text { Lard }\end{array}$ & $\begin{array}{c}\text { Rf.9+0.2\% } \\
\text { Lard }\end{array}$ & $\begin{array}{c}\text { Rf. } 10+0.2 \% \\
\text { Lard }\end{array}$ & $\begin{array}{c}\text { Significant } \\
\text { difference }(99.7 \%)\end{array}$ \\
\hline R & 36.33 & 39.13 & 30.14 & 42.98 & 33.37 & 41.93 & $>34.62$ \\
EFpalm & 0.52 & 0.51 & 0.50 & 0.58 & 0.50 & 0.55 & $>0.49$ \\
\hline
\end{tabular}


technique of fatty acids in the $\beta$ position allowing to obtain the $E F$ palm value that have proven significantly sensitive $(p>0,997)$ to $0.2 \%$ lard contamination ( $2 \%$ fat basis) in the type of product tested.

\section{BIBLIOGRAPHY}

A.I.I.B.P. (1990).-«Analytical Methods for the Soup Industry».-Technical Commission of the International Association of the bouillon and soup industry (A.I.I.B.P.).-Berne.

El-Khalafy, H. M., Fadel, H. M., Soliman, M. M. A. y Osman, F (1987a).- «Adulterated beef fat: Fatty acid composition».-Grasas y Aceites 38, 85-86.

El-Khalafy, H. M., Fadel, H. M. y Soliman, M. M. A. (1987b).-«Adulterated beef fat: The structure of triglycerides and 2-monoglycerides".-Grasas $y$ Aceites 38, 176-179.

El-Sayed, L., Ahmad, Abdel Kader S. and Amer, Mohamad M. (1985).- «Detection of lard in hydrogenated fats».-Riv. Ital. Sostanze Grasse 62, 553-557.

Fadel, H. M. y Soliman, M. M. A. (1989).-«Volatile components of the adulterated roasted beef fat».-Grasas y Aceites 40, 345-350.

Fahmy, L., El-Sakr y Farag, H. (1988).-“Biophysics - chemical ways on the detection of different fatty sources adulterated with each others in our local market".-Grasas y Aceites 39, 143-146.

Rugraff, L., Karleskind, A. (1983).-«Analyse des mélanges de graisses animales. Aplication au contrôle de l'absence de graisse de porc dans les suifs et subsidiarement dans les produits carnés et derivés crus ou cuits».-Rev. Fr. Corps Gras 30, 323-331.

Saeed, T., Abu-Dagga, F. y Rahman, H. A. (1986).-«Detection of pork and lard as adulterants in beef and mutton mixtures".-Assoc. Off. Anal. Chem. 69, 999-1002.

Saeed, T., Ali, S.G., Abdul-Rahman, H. A. J. y Sawaya, W. N (1989).- «Detection of pork and lard as adulterants in processed meat: liquid chromatographic analysis of derivatized triglycerides".-Assoc. Off. Anal. Chem. 72, 921-925.

Wolff, J. P. y Audiau, F. (1964).-“Contrôle de l'origine des suifs par chromatographie en phase gazeuse».-Rev. Fr. Corps Gras 11, 77-89.

Wolff, J. P. (1968).-«Manuel d'analyses des corps gras».-p. 315.-Ed. Azoulay.-París.

Youssef, M. K. E., Omar, M. B. E., Skulberg, A. y Rashwan, M. (1986a).- «Lypolisis and fractionation of triglycerides by argentation TLC in lard and beef tallow mixtures".-Proceedings of the European Meeting of Meat Research Workers 32 - Vol. II. 9,8 - 451-454.

Youssef, M. K. E., Omar, M. B. E., Skulberg, A. y Rashwan, M (1986b).- «Estimation of lard in beef tallow by gas liquid chromatography».-Proceedings of the European Meeting of Meat Research Workers 32 - Vol. II. 9,9 - 455-457.

Youssef, M. K. E. y Rashwan, M. (1987).- «Detection and evaluation of lard adulteration in pure buffalo and cow butter».-Proceedings of the European Meeting of Meat Research Workers 33 - Vol. II. 8,4 - 373-376.

Youssef, M. K. E., Omar, M. B. E., Skulberg, A. y Rashwan, M. (1988).- «Detection and evaluation of lard in certain locally processed and imported meat products».-Food Chem. 30, 167-180.

(Recibido: Septiembre 1992) 